Научная статья /

Research Article

УДК 821.І6І.І.о

ББК $83.3(2 \mathrm{Poc}=\mathrm{Pyc}) 53$
МЕЖДУ ОТТО ВЕЙНИНГЕРОМ

И В.В. РОЗАНОВЫМ: О КОНСТРУИРО-

ВАНИИ ФЕМИНИННОСТИ

И МАСКУЛИННОСТИ В ТВОРЧЕСТВЕ

Д.С. МЕРЕЖКОВСКОГО

Аннотация: Имея революционные взгляды на христианство, Д.С. Мережковский был, с одной стороны, вполне традиционен в понимании роли Бога в отношении разделения полов, а с другой - склонялся к идее платоновского андрогинизма, рассматривая в этом аспекте природу Христа. Совмещение идей личности и пола, Тайны Одного и Тайны Двух, по мысли Д.С. Мережковского, приведет к историческому объединению язычества и христианства, к тайне Трех - Обществу, понимаемому как Царство Божие. В этом он идет дальше В. Розанова, также писавшего о двуполой природе Христа. Кроме того, Д.С. Мережковский широко использует высказанную О. Вейнингером идею имманентной двуполости человека, отвергая при этом его положение о том, что женщина не обладает «личностью» и «метафизическим бытием». Опираясь на В. Розанова в необходимости введения идеи пола в религию и на О. Вейнингера в идее двуполости, Д.С. Мережковский, как показано, занимает некое срединное положение между ними.

ключевые слова: Дмитрий Мережковский, Василий Розанов, Отто Вейнингер, фемининность, маскулинность, андрогин, пол, гендер.

Информация об авторах: Анна Викторовна Протопопова - кандидат филологических наук, старший научный сотрудник, Институт мировой литературы им. А.М. Горького Российской академии наук, ул. Поварская, д. 25 а, І2Іо69 г. Москва, Россия. ORCID ID: http://orcid.org/oooo-ooo2-446I-3349 E-mail: avprotopopova@yandex.ru

Иван Алексеевич Протопопов - кандидат философских наук, доцент, СанктПетербургский государственный университет аэрокосмического приборостроения, ул. Большая Морская, д. 67, лит. А, І90ооо г. СанктПетербург, Россия. ORCID ID: https://orcid.org/oooo-0003-2242-55I2 E-mail: stiff72@mail.ru

Для цитирования: Протопопова А.В., Протопопов И.А. Между Отто Вейнингером и В.В. Розановым: о конструировании фемининности и маскулинности в творчестве Д.С. Мережковского // Studia Litterarum. 202I. Т. 6, № 3. С. 204-22I. https://doi.org/I0.22455/2500-4247-202I-6-3-204-22I 


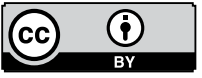

This is an open access article distributed under the Creative Commons Attribution 4.0 International (CC BY 4.0)

Studia Litterarum, vol. 6, no. 3, 202I

\section{BETWEEN OTTO WEININGER AND VASSILY ROZANOV: CONSTRUCTING THE FEMININE AND THE MASCULINE IN DMITRY MEREZHKOVSKY'S WORKS}

\author{
(C) 202I. Anna V. Protopopova, Ivan A. Protopopov \\ A.M. Gorky Institute of World Literature \\ of the Russian Academy of Sciences, \\ Moscow, Russia; Saint-Petersburg State University \\ of Aerospace Instrumentation, St. Petersburg, Russia \\ Received: April I6, 2020 \\ Approved after reviewing: May 29, 2020 \\ Date of publication: September 25, 2021
}

Abstract: Despite his revolutionary views on Christianity, Merezhkovsky believed in the traditional role of God concerning gender distinction and was attached to the Plato's idea of androgyns, considering the nature of Christ in androgynous terms. The combination of the notions of gender and personality, that is, the Mysteries of the One and of the Two, must lead, according to Merezhkovsky, to the historical unison of paganism and Christianity, to the Mystery of the Three, e.g. to the Society understood as the Kingdom of Heaven. In this aspect, he moves beyond Rozanov, who also wrote on the bi-gendered nature of Christ. Merezhkovsky widely uses Weininger's idea of immanent bisexuality of a person while he dismisses Weininger's thesis that a woman does not possess personality and metaphysical being. Taking into account Rozanov's suggestion of introducing gender in religion and Weininger's idea of bisexuality, Merezhkovsky, as the article shows, occupies a somewhat middle position.

Keywords: Dmitry Merezhkovsky, Vassily Rozanov, Otto Weininger, feminine, masculine, androgyn, sex, gender.

Information about the authors: Anna V. Protopopova, PhD in Philology, Senior Researcher, A.M. Gorky Institute of World Literature of the Russian Academy of Sciences, Povarskaya 25 a, I21069 Moscow, Russia.

ORCID ID: http://orcid.org/oooo-0oo2-446I-3349

E-mail: avprotopopova@yandex.ru

Ivan A. Protopopov, PhD in Philosophy, Associate Professor, Saint-Petersburg State University of Aerospace Instrumentation, Bolshaya Morskaya 67, lit. A, I900oo St. Petersburg, Russia. ORCID: https://orcid.org/o000-0003-2242-5512

E-mail: stiff72@mail.ru

For citation: Protopopova, A.V., Protopopov, I.A. "Between Otto Weininger and Vassily Rozanov: Constructing the Feminine and the Masculine in Dmitry Merezhkovsky's Works.” Studia Litterarum, vol. 6, no. 3, 202I, pp. 204-22I. (In Russ.) https://doi.org/I0.22455/2500-4247-202I-6-3-204-22I 
Вопрос о гендере и половых различиях стоял довольно остро в эпоху модернизма ${ }^{\mathrm{I}}$, так что книга австрийского философа Отто Вейнингера «Пол и характер», напечатанная в Европе в г903 г., была, можно сказать, обречена на успех. Первый полный русский перевод «Пола и характера», выполненный Владимиром Лихтенштадтом, с предисловием и под редакцией Акима Волынского, вышел в издательстве «Посев» в августе І908 г. [24], а до І9І2 г. были напечатаны несколько десятков тысяч экземпляров различных переводов этой книги! В своей рецензии на книгу в г909 г. Николай Бердяев отмечает сильные и слабые стороны позиции О. Вейнингера и говорит, что «так хотелось бы, чтобы Вейнингера оценили, и так не хотелось бы, чтобы вейнингерианство стало модой» [20].

К сожалению или к счастью, но если вейнингерианство и не стало полноценным модным течением, то по меньшей мере идеи молодого австрийца вызвали великое множество откликов, снискали невероятную популярность среди символистов: Вяч. Иванов [27], Андрей Белый [23], Зинаида Гиппиус [26], Василий Розанов и многие другие писали на него рецензии, обсуждали, ссылались в своих трудах и т. п. Среди тех, кто не прошел мимо книги, был и Д.С. Мережковский. В статье мы постараемся

I См., например, монографию Кирсти Эконен о стратегиях женского письма в русском символизме [15].

2 На подсчеты Эрика Наймана [18] ссылается в своей статье Евгений Берштейн [3, прим. 3]. Специальных больших исследований влияния О. Вейнингера на русскую литературу, за исключением статьи Е. Берштейна, насколько можно об этом судить, на данный момент нет; в основном этому посвящены статьи или отдельные параграфы или главы книг по русскому модернизму (например, глава «Антропологическая утопия Отто Вейнингера» в монографии А.И. Жеребина [6, с. 29I-318] или статья Р. Деринг-Смирновой [5]). 
разобрать его отношение к вопросам пола и идеям О. Вейнингера, проявившееся в трилогии о Троицез.

Трилогия Д.С. Мережковского «Тайна Трех: Египет и Вавилон»; «Тайна Запада: Атлантида-Европа» и «Иисус Неизвестный» посвящена литературно-художественному осмыслению судьбы человечества, которое, отвергнув свое единство с Богом, обрекает себя на духовную и физическую гибель, впадая в состояние всеобщей губительной войны. Прообраз этого конца Европы писатель видел в гибели мифической платоновской Атлантиды, исследованию которой он уделил серьезное внимание во второй книге трилогии («Тайна Запада: Атлантида-Европа»). Как считал О.А. Коростелев, «центральное содержание трилогии - человечество, гибнущее оттого, что не восприняли весть Иисуса либо поняли ее неправильно. Мережковский здесь выступает и как огненный пророк, предостерегающий, направляющий и взывающий, и одновременно как мрачный скептик, заранее уверенный в том, что все его призывы не будут услышаны. Он жаждал царства Святого Духа, звал к нему и путь видел лишь один - путь следования Третьему Завету» [9, с. 770].

В понимании писателя господство христианства в Европе вовсе не привело к его истинному воплощению в жизни народов, выродившись в оторванный от реального мира аскетический духовный идеал, отвергнутый большинством вместе с Христом, в силу чего результатом мировой истории в любом случае будет Апокалипсис, явление антихриста, о котором говорится в Евангелии, и второе пришествие Христа с осуществлением Царства Духа в конце мировой истории 4 . Этот собственно христианский сюжет мировой истории преломился в видении создателя трилогии в совершенно иное понимание религиозного смысла христианства, которое как таковое глубоко укоренено и происходит из язычества, как считал Д.С. Мережковский, реализуя себя в то же время через противостояние ему. Таким образом, собственно основные религиозные христианские принципы имеют

3 Здесь и далее все ссылки на тексты Д.С. Мережковского указываются по изданию 20I7 г. [30].

4 Как отмечает А.А. Холиков, «писатель критикует средневековое христианское толкование духа как сущности, запредельной тварному миру, и активно противостоит категорическому размежеванию духа и плоти как не имеющих точек соприкосновения субстанций, а также - превознесению духа над плотью в христианской догматике и лишению плоти ореола святости» [14]. 
куда более древнее происхождение: бессмертие человеческой души, воплощение Бога, его смерть и воскресение, которое приведет к воскресению мертвых, предвоплотились уже в Египте и Вавилоне («Тайна Трех: Египет и Вавилон»), но не устояли перед разрушительными силами зла, воплощенного в фигуре антихриста.

При этом как спасительное последующее воплощение Христа, так и уничтожающее род человеческий дьявольское воплощение антихриста связаны с телесно непосредственным началом пола, через которое, как считал Д.С. Мережковский, реализует себя вовсе не только человеческая, но и божественная природа. Как показал В. Базаров, в общих чертах символическое понимание христианской Троицы, которое мы находим в его трилогии, сложилось у него уже в сборнике статей «Не мир, но меч» (I908), но именно в его трилогии оно нашло полное художественное воплощение [2, с. 200-20I].

Исходя из того религиозного содержания, которым были проникнуты мифопоэтические конструкции Д.С. Мережковского, может создаться видимость, что он занимался в своих литературных произведениях философскими и теологическими штудиями, но это совершенно не так, поскольку в трилогии он непосредственно-интуитивно, художественно осмысливает проблемы, связанные с отношением Бога и человека, как имеющие непосредственное отношение к жизни в целом и искусству, апеллируя по большей части не к пониманию, а к внутреннему чувству и мистическому духовному единству.

Н. Бердяев писал по этому поводу, что «Мережковский живет в литературных отражениях религиозных тем, не может мыслить о религии и писать о ней иначе, как исходя из явлений литературных, от писателей. Прямо о жизни Мережковский не может писать, не может и думать. Он - литератор до мозга костей, более, чем кто-либо» [2I, с. 33I]. То, какое ошеломляющее воздействие на читателя производили фантастические конструкции Д.С. Мережковского, связанные с именем Бога, хорошо показывает А. Блок. Он пишет, что, открыв и перелистав его последние книги, «можно прийти в смятение, в ужас, даже - в негодование. "Бог, Бог, Бог, Христос, Христос, Христос”, положительно нет страницы без этих Имен, именно Имен, не с большой, а с огромной буквы написанных - такой огромной, что она все заслоняет, на все бросает свою крестообразную тень, точно 
вывеска "Какао” или “Угрин” на Загородном, и без нее мертвом, поле, над “холодными волнами” Финского залива, и без нее мертвого» [22, с. 242]. Действительно, если прослеживать эволюцию в изображении персонажей у Д.С. Мережковского, то можно увидеть, что Юлиан Отступник, Леонардо да Винчи, Петр I - это лишь некоторые исторические воплощения таких грандиозных, божественных или дьявольских, управляющих всем миром сил, которые только в его трилогии становятся, наконец, непосредственными литературными персонажами5.

Тем не менее, несмотря на фантастичность своих представлений о поле, Д.С. Мережковский изначально опирался на традиционные христианские воззрения, согласно которым человечество создано Богом как разделенное на мужчин и женщин. Единство этих полов образует человеческую личность. При этом низшая форма реализации такого единства, половое соитие, является, согласно Д.С. Мережковскому, выражением не Божественного, а дьявольского начала. «Половая любовь есть неоконченный и нескончаемый путь к воскресению, - пишет он. - Тщетно стремление двух половин к целому: соединяются и вновь распадаются; хотят и не могут воскреснуть - всегда рождают и всегда умирают» [30, с. II5].

Для Д.С. Мережковского, таким образом, имеют большое значение идеи Платона, связанные с его знаменитым мифом об андрогинах, изначально цельных двуполых существах, разделенных и вечно ищущих свою «вторую половину». Эти половины хотят соединиться, но не могут обрести подлинного единства, так как остаются различными существами ${ }^{6}$ Только через

5 О религиозно-христианских основаниях литературного творчества Д.С. Мережковского, реализованных в полной мере в трилогии, и о центральной фигуре этого творчества, которой посвящено последнее ее произведение, прямо писал хорошо его знавший Г.В. Адамович: «Мережковский, конечно, думал о Евангелии всю жизнь и шел к “Иисусу Неизвестному” через все свои прежние построения и увлечения, издалека глядя в него, как в завершение и цель. Иногда бывали зигзаги, со стороны не совсем понятные, - например, один из его последних зигзагов: наполеоновский, - но в сознании Мережковского они едва ли были отклонениями. Наоборот, все должно было внести ясность в единственно важную тему и подготовить рассказ и размышление о том, что произошло в Палестине девятнадцать столетий тому назад. Нет писателя, который был бы больше однодумом, чем он. Ему не приходилось ни обуздывать себя, ни бороться с “впечатлениями бытия”: жизнь для него - не то, что есть, а то, что должно быть. Он готов был бы повторить: “тем хуже для фактов”, если бы нашел что-либо не укладывающееся в его схематически стройные - что-то уж слишком стройные! - исторические догадки. Да он и видел лишь то, что к схемам его подходило, так что недоразумений или трудностей не возникало» [19, с. 394].

6 Платон. Пир. 189е-I9Id [3I, т. 2, с. 98-гоо]. 
возвышение над материальным и чувственным от любви к прекрасным телам до любви к душе, а затем до любви к прекрасному самому по себе, которое реализуется в высшем божественном благе, достигается это единство ${ }^{7}$.

Пол в этом смысле есть только «половина личности, мужская или женская. Корень смерти есть половой расщеп, распад личности. Сквозь этото “открытое место” в теле, где прошел “волос, яйцо разрезающий”, и входит смерть. А смерть победить, воскреснуть - значит восстановить целую личность, исцелить зияющую рану пола. Целая, исцеленная личность для смерти закрыта, замкнута, как совершенный круг или шар - “солнечный шар” Скарабея, “двуполый шар” Андрогина» [30, с. II5]. Платоновская тема объединения двух половинок (мужского и женского) как достижения высшего единства человеческой природы была намечена в русской философии В.С. Соловьевым, который считал, что для того, «чтобы оправдать на деле тот смысл любви, который сначала дан только в чувстве; требуется такое сочетание двух данных ограниченных существ, которое создало бы из них одну абсолютную идеальную личность» [32, с. 25].

Андрогинам у Д.С. Мережковского посвящена отдельная, восьмая главка «Тайны Запада», где они уподобляются атлантам, этим существам конца цивилизации; в то же самое время андрогин - это и дьявол. «Дьявол, “обезьяна Бога”, подражает ему во всем, - и в этом: бог Содома, Андрогин, - искаженный, страшно сказать, в дьявольском зеркале, Сын» [3о, c. 368]. В физическом смысле он являет собой тот самый образ соединения двух полов, которое не дает, грубо говоря, положительного результата. В то же время андрогин у Д.С. Мережковского символизирует и то самое искомое духовное единство: «каждый Атом есть бог Андрогин или Бэтиль, Мужеженщина; самое существо Материи - Богоматерии - мужеженское. Космос есть явление двуполого Эроса-Логоса» [30, с. 378].

Как пишет Е.А. Андрущенко, «весь Египет Мережковского проникнут половой символикой, <...> именно насыщенность полом делает египетскую цивилизацию самой близкой к пониманию святого пола, то есть исполнению будущего пророчества “Будут двое одна плоть” [г, с. 782]. При этом Д.С. Мережковский проводит параллель не только между Египтом и христианством, но и между Вавилоном и христианством, где Осирису и за- 
тем Христу уподобляется бог Таммуз. «Вавилон представляет собой, - по мысли Д.С. Мережковского, - невозможное для христианства разрушение бесконечной цепи рождения и смерти. В Вавилоне соединение мужчины и женщины есть дар богине, а в Бытии - блуд и мерзость. 'То, что мы называем “цивилизацией”, движется в том, что мы называем “прогрессом”, - в поступательной смене родов, рождений, в половой динамике. Вот почему “маленькая ошибка" в передвижении рельсовой стрелки, именно здесь, в точке пола, может погубить весь прогресс и всю цивилизацию. Эту маленькую ошибку мы и сделали, вынув религиозную душу из пола’ [30, с. 783$]^{8}$.

Пытаясь вернуть христианство в идею пола, Д.С. Мережковский рассуждает о мужеженственности Бога и Христа. «Три Бога - Два в Одном - создают человека по образу Своему - двух в одном. "И сотворил Бог человека; по образу Своему, по образу Божию, сотворил его; мужем и женою сотворил $u x "$ (Быт. г: 26-28). Сначала - “его”, Мужеженщину, а потом - “их”, мужчину и женщину: два пола в одном существе - вот что значит "образ Божий” в человеке. Кажется, нельзя яснее выразить догмат божественной двуполости: Андрогин создает Андрогина» [3о, с. 462]. Двуполость Бога как бы подтверждается у Д.С. Мережковского квазиевангельскими цитатами об отсутствии в Царствии Небесном мужчин и женщин, которые «будут одно»9: «Первый человек, бессмертный, до грехопадения, есть Адамо-Ева, Мужеженщина; и Последний, Воскресший - тоже» [30, с. II5].

В Богочеловеческой природе Христа воплощается единство мужской и женской человеческой природы. В Христе как бы нет ни мужского, ни женского, но все реализовано в единстве со своим противоположным началом. Мужской Египет и женский Вавилон соединяются, чтобы породить Израиль, двойное существо, которое предвосхищает Христа. Именно потому, что пол изымался в исторической христианской церкви из понятия о Боге, как считает Д.С. Мережковский, «не исполнилось царство Божие и в христианстве, так же как в язычестве. Здесь, в христианстве, личность без

8 Цит. из Тайны Трех [3о, с. 206].

9 К евангельской идее брака, когда мужчина и женщина сливаются в одно (Еф. 5: 3I), Д.С. Мережковский присоединяет евангельскую же идею о том, что в Царствии Небесном не женятся и не выходят замуж (Мф. 22: 30; Лк. 20: 34-36), и идею св. Климента Александрийского из «Стромат», что в Царствии Небесном «двое станут одним, мужчина сольется с женщиной, и не будет ни мужчин, ни женщин”» (Кн. 3. XIII. 92. 2 [28, с. 445]). Ср.: [30, с. 2I2, $218,464]$. 
пола; там, в язычестве, пол без личности. А только тогда, когда исполнится тайна Одного и тайна Двух - Личность и Пол, исполнится и тайна Трех Общество», - понимаемое им как будущее Царство Божие [30, с. 36].

Это некоторым образом совпадает с идеями В. Розанова, на которые Д.С. Мережковский опирается: «Тайна Одного в Тайне Двух есть личность в поле. “Личность есть равноденствие обоих полов” (В. Розанов. Люди лунного света, 285)» [30, с. II5]. В. Розанов также писал и о мужеженской природе Христа, его слова прямо цитирует сам Д.С. Мережковский [30, с. II5]: «Взгляните на изображение Его... Нежное, прекрасное лицо, прекраснейшее на земле... Девство, нежность, женственность, просвечивающая сквозь мужские признаки... Две природы в нем, и полнота в Нем человечности, закругленная, завершенная, чего и не может быть только в одном мужском или только в одном женском (Розанов, <Люди лунного света>, І89) ${ }^{\text {го }}$. В. Розанов в то же время занимал в целом критическую позицию в отношении христианства, рассматривая его как бесплотную религию, в которой отвергается половая основа всей жизни, а отказ от брака выступает высшим достижением духа ${ }^{\text {II }}$. Именно В. Розанов впервые в русской культуре вводит идею пола в религию, но не делает отсюда настолько далеко идущих выводов, как Д.С. Мережковский ${ }^{\text {12 }}$. В отличие от В. Розанова, двуполая природа Христа переносится Д.С. Мережковским не только на духовную суть людей, но и на божественную природу в целом ${ }^{\mathrm{I}}$.

Iо Как считает Е. Берштейн, «В России теорию пола, родственную вейнингеровской, выстроил В.В. Розанов в книге “Люди лунного света. Метафизика христианства” (г9І г. первое издание, г913 г. - второе, существенно дополненное). В своих рассуждениях о текучести пола в человеке Розанов не ссылается на Вейнингера, и, возможно, он (как и 3. Гиппиус) пришел к ним независимо от австрийского философа, на основе знакомства с общими источниками - сексологическими сочинениями Рихарда Краффт-Эбинга, Августа Фореля, Магнуса Гиршфельда и др. Однако культурфилософские заключения, сделанные Розановым из описанных современной наукой феноменов половой жизни, были диаметрально противоположны выводам Вейнингера: австрийский философ был против полового влечения и сексуальности, а Розанов - обеими руками за» [6]. Сравнению концепций пола и брака у Д.С. Мережковского и В. Розанова в их соотнесении с христианством посвящена статья М. Ким [8].

II См. подробнее об этом в статье И.В. Брылиной [4]

I2 Как считает А.Б. Сурова, перед В. Розановым стояла сложная задача: опровергнуть «христианские идеи плотского греха и воздержания, утвердить идею человека как сексуального существа в христианской культуре. Таким образом, своеобразная критическая позиция по отношению к историческому христианству и Новому Завету, занимаемая философом, является следствием подобной попытки» [13].

I3 Как полагает В.В. Полонский, розановский концепт пола, интерпретированный в религиозно-космологической перспективе, становится лейтмотивом историософии Д.С. Ме- 
Как пишет А.Н. Николюкин, пытаясь отыскать источники таких воззрений, «Так называемое “новое религиозное сознание”, провозвестником которого выступал Мережковский, образовалось из двух течений: из того, что Достоевский в своей Пушкинской речи назвал "русским мировым скитальчеством" и из второго, более практического источника, который был ближе Розанову, а не Мережковскому - из нужд и потребностей семейной жизни человека. Историческое христианство, утверждал Мережковский, всемерно подчеркивало духовное начало, что привело к отрицанию святости плоти, мистического единства духа и плоти в их равноценности» [II, с. I5].

Другой важный аспект в разработке Д.С. Мережковским идей пола связан с той немалой ролью, которую сыграла в ней книга О. Вейнингера «Пол и характер». Австрийский философ в своих воззрениях на пол отрицал метафизическую сущность и значение женской природы. Обычная со времен Античности идея доминирования мужчин в обществе связывалась с тем, что онтологический статус мужчины представлялся как выражающий всеобщую форму и сущность человеческой природы вообще, мужское начало понималось как существующее независимо от женского и являющееся основанием всех свойств человеческой природы (разумности, способности к познанию). Женщина, несмотря на способность продолжения рода, равноправной мужчине не являлась. Женское начало соответствовало принципам изменчивой порождающей материи, матери-кормилицы, в которой возникают все чувственно воспринимаемые вещи ${ }^{\mathrm{I4}}$, но которая, сама по себе будучи бесформенной, выражает лишь возможность их бытия, а не действительное существование. Сама по себе не обладая бытием, она есть не-сущее, которое, как писал Платон в «Тимее», воспринимая отпечатки всех вечно сущих идей ${ }^{15}$, дает место всему, что имеет возникновение ${ }^{16}$. Мужское же начало - деятельное, имеющее самостоятельное бытие, относящееся к умопостигаемой идее или форме всего сущего ${ }^{17}$.

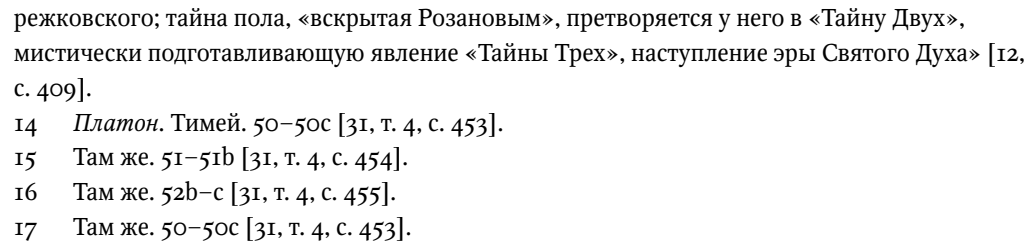


Наследником этих представлений в определенном смысле и выступает О. Вейнингер. Для него женщины лишены не только понимания, логики и этики, но даже и души. В каждом существе заложены изначально две природы, мужская и женская, далее какая-то начинает преобладать до определенной степени, причем соотношение этого преобладания (например, семьдесят процентов мужского и тридцать процентов женского) обеспечивает стремление к обратно пропорциональному соотношению этих начал в человеке «противоположного пола», именно человеке, потому что для О. Вейнингера пол не является ни чем-то социальным, ни чем-то биологически предустановленным на сто процентов, ведь может так оказаться, что в «мужчине» в процентном отношении больше женского начала, чем мужского. Мужское и только мужское начало способно, по О. Вейнингеру, к творчеству, познанию и тому подобному, женское же начало, имея исключительно чувственную природу, низменно и предназначено только для размножения. В соитии О. Вейнингер видит «свинство» и скотство, которого, естественно, следует избегать. О. Вейнингер, таким образом, подводит итог традиции преобладания мужского начала, заявляя о полном доминировании мужчины. Казалось бы, в таких взглядах не может быть ничего близкого идее пола у Д.С. Мережковского, но это оказывается не так.

В первую очередь идея двуполости всего живого, высказанная О. Вейнингером, импонирует Д.С. Мережковскому, в этой связи он несколько раз его цитирует ${ }^{18}$. В целом это вполне соответствует и мысли В. Розанова, и мысли Вл. Соловьева, одну из статей которого в цикле «Смысл любви» Д.С. Мережковский цитирует: «Пребывать в половой раздельности - значит пребывать на пути к смерти... Кто поддерживает корень смерти, тот вкусит и плода ее. Бессмертным может быть только целый человек» [30, с. II5]. Однако для обоих этих философов половое соитие вовсе не является чем-то ужасным, даже и напротив, оно являет собой акт единения противополож-

I8 О близости идеи двуполости, которая вводится Д.С. Мережковским в божественную природу, построениям платоновского «Пира» и концепциям биполярности О. Вейнингера пишет В.В. Полонский: «Своеобразным синтезом философем “женско-мужского начала в Боге” и “пола в любви” явилось учение об андрогине в духе платоновского “Пира” и последующей гностической традиции. Правда, непосредственные предпосылки к особо активному усвоению Мережковским этой темы были заданы гораздо более близкими по времени источниками - концепциями биполярности и бисексуальности О. Вейнингера» [12, с. 4I3]. 
ных полов, между тем как О. Вейнингер призывает к аскетизму и отказу от всякого телесного общения с женщинами.

Влияние О. Вейнингера на Д.С. Мережковского, возможно, было опосредовано также представлениями его собственной жены о себе как о существе, совмещающем в себе мужской и женский пол именно в соответствии с концепцией Вейнингера. Как пишет О. Матич, «заявления [Гиппиус], что интеллектуально и духовно она маскулинна, отражают те же женофобские предрассудки, что у Вейнингера, считавшего, что для женщин актуально только тело и они ищут лишь сексуальных удовольствий. Относясь снисходительно к женскому полу, Гиппиус в дневнике представляет свое влечение как мужское» ${ }^{19}$. Во многом Д.С. Мережковский, конечно, критикует О. Вейнингера, объединяя, например, его с Декартом и объявляя его идеи идеями «обезумевшего разума», говоря о нем как о бывшем иудее, который хорошо знаком с тем, что такое Израиль и «пустыня чистого разума» ${ }^{20}$. Он (справедливо) называет его женоненавистником в противовес тому, что представляет собой «Розанов, противоположный двойник Вейнингера, женолюбец», ведь в отличие от О. Вейнингера философы русского модернизма превозносили женскую природу, и В. Розанов в этом особенно преуспел ${ }^{21}$. Женская природа понималась как нечто снимающее западную приверженность рациональному пониманию действительности, как порождающее начало.

Не близки Д.С. Мережковскому и идеи О. Вейнингера относительно отсутствия пола в Царствии Небесном, которые значительно ближе у последнего к традиционному пониманию христианства. Между тем Д.С. Мережковский вовсе не солидаризируется с В. Розановым, не объединяется с ним против О. Вейнингера: «Розанов и Вейнингер недаром противоположные двойники-современники: в них воплотилась раздирающая нас антино-

I9 Глава 5. По ту сторону гендера. Переписка как телесное слияние. URL: https://www. twirpx.org/file/IoI8970/ (дата обращения: го.о4.2020) [Іо]. См. также статьи 3. Гиппиус о любви, где среди прочего разбираются вопросы пола у Д.С. Мережковского и В. Розанова [25]. 20 «...мы уже <...> бежали из Египта, от нечистой животности, в пустыню “чистого разума”, где и блуждаем доныне вместе с Израилем. Чистый разум Декарта не соблазняется никакою животностью: для него сами животные - только “машины”, “автоматы”. И можно сказать, что весь наш век - век чистого разума и чистой механики - родился от этой Декартовой машины. Вейнингер, иудей-христианин, идет еще дальше Декарта. По Вейнингеру, женщине “бытие метафизическое присуще так же мало”, как животным и растениям. Так, вся живая тварь уничтожена обезумевшим разумом, огнем попаляющим иудео-христианской пустыни, “умным и страшным Духом небытия” [30, с. 72-73].

2 I О В. Розанове и О. Вейнингере см. в книге Лоры Энгельштейн [I7]. 
мия: пол в Отце, противопол в Сыне. “Пол имеет свое содержание и положение трансцендентно-религиозного нумена (сущности). Он - второе, темное лицо человека. Он выходит из границ естества; он внеестествен и сверхъестествен... Это пропасть, уходящая в антипод бытия, здесь, и единственно здесь, выглянувший в наш свет, - говорит В. Розанов. $-<\ldots>$ Дионис и Аид - один и тот же бог”; пол и смерть - одна и та же пропасть, уходящая из этого мира в тот. Пол есть единственно живое, кровно-телесное “касание мирам иным”, единственный выход из своего тела в чужое, из я в ты, из тайны Одного в тайну Двух» 22 .

Здесь Д.С. Мережковский идет дальше их обоих, устремляясь от Тайны Двух к Тайне Трех, опираясь сразу и на В. Розанова, и на О. Вейнингера. Его идея Тайны Трех, троичность, которую никто не замечает, а сам он видит везде, обосновывается на самом высшем уровне. Это Троица, которая включает в себя идею Личности (тайна Одного), Пола, который воплощается в Христе (тайна Двух), и Общества как царства Духа (тайна Трех).

Свое завершение идея пола, введенная Д.С. Мережковским в христианскую Троицу, находит в толковании Святого Духа как Божественной Матери, через которую будет воплощаться Царство Божие: «В явной жизни Сына - Отец; в тайной - Мать. Весь Иисус Известный - в Отце; весь Неизвестный - в Матери. Если есть у Сына Отец Небесный, может ли не быть и Небесной Матери? <...> Больше, чем когда-либо, сейчас упование рода человеческого есть матерь Сына земная, Дева Мария. Люди поклонились ей недаром: только Она и ведет их к Матери Небесной - Духу». В соответствии с этим выстраивается история человечества: «Три человечества: первое, до нас погибшее, - Царство Отца; второе, наше, спасаемое или погибающее, третье, за нами, спасенное, царство Духа - Матери» [29, с. I77].

Как пишет В.Н. Жуков, Третий Завет Д.С. Мережковского, посвященный тысячелетнему Царству Духа, «исполняется в исторически-реальном, небесно-земном и духовно-плотском царстве Божием - воплощении Третьей Божеской Ипостаси (Святого Духа-Матери). Это будет означать также образование на этапе Третьего Завета единой Вселенской Церкви Богочело-

\footnotetext{
22 Между тем традиционное христианство, с точки зрения Д.С. Мережковского, приходит к уничтожению идеи пола и таким парадоксальным образом ведет к безбожию: «...в христианской динамике пол и противопол сначала борют друг друга, а потом уничтожают. Наступает небытие пола в религии, половое безбожие, может быть, корень всех остальных безбожий, личных и общественных» [30, с. Іо7].
} 
вечества, где, по убеждению Д.С. Мережковского, совершится неизвестная Евхаристия Иисуса Неизвестного и каждая отдельная личность станет реально частью тела Христова и победит смерть физически» $\left[7\right.$, с. 682-683] ${ }^{23}$.

В отношении пола у Д.С. Мережковского также имеется идея троичности: это мужское начало, женское и мужеженское, платоновский андрогинизм, понятый уже в высшем, духовном смысле. Переходя от Платона к рассуждениям на тему однополой любви, возможно, даже неожиданно для самого себя Д.С. Мережковский делает вывод, что возражения против нее бессмысленны: она не противоестественна, так как в природе есть еще и не такое, нет и проблемы продолжения рода, отсутствующего в подобных связях, поскольку мир ужасен, и почему именно «нужно», чтобы род продолжался в таком мире, неясно.

В эпоху модернизма, таким образом, уже можно констатировать смещение полов, а третий пол Платона в XX в. постепенно приобрел статус законного действия, при снижении уровня влияния христианства, что в целом закономерно предсказал Д.С. Мережковский. В условиях отсутствия идеи Божественного разума и освобождения человека от изначальной заданности своей природы исчезают различия между полами, и, собственно, пол теряет всякий смысл, ибо он уничтожается такого рода возможностью выбора. Это было предвидено в модернизме. Смешение полов или выделение третьего пола, быть может, и привело в конечном итоге к отсутствию определенности человеческого существования в принципе.

\section{Список литературы \\ Исследования}

I Андрущенко Е.А. Несвоевременная книга // Мережковский Д.С. Собр. соч.: в 20 т. М.: Дмитрий Сечин, 2017. Т. г4: Тайна Трех: Египет и Вавилон; Тайна Запада: Атлантида-Европа / сост., подгот. текста, послесл., коммент. О.А. Коростелева и Е.А. Андрущенко при участии А.В. Журбиной. С. $77^{6-788 .}$

2 Базаров В. Христиане Третьего Завета и строители Башни Вавилонской // Мережковский: pro et contra. Личность и творчество Дмитрия Мережковского в оценке современников: антология. СПб.: РХГА, 200г. С. 197-24I.

3 Берштейн Е. Трагедия пола: две заметки о русском вейнингерианстве // Новое литературное обозрение. 2004. № 65. С. 208-228. https://magazines.gorky.media/

23 О том, какое значение имеет в Третьем Завете Д.С. Мережковского понимание Духа как Божественной Матери, подробно пишет Ч. Гарольд Бедфорд [І6, с. г6I], цит. по: [І2, с. 404]. 
nlo/2004/I/tragediya-pola-dve-zametki-o-russkom-vejningerianstve.html (дата обращения: Іо.04.2020).

Брылина И.В. Пол как исток жизни: В.В. Розанов, Л.Н. Толстой, М.И. Цветаева // Известия Томского политехнического университета. 2007. Т. 3ІІ, № 7: Философия, социология и культурология. С. 98-го3.

Деринг-Смирнова Р. Пастернак и Вейнингер // Новое литературное обозрение. 1999. № 37. С. 63-69.

6 Жеребин А.И. Вертикальная линия. Венский модерн в смысловом пространстве русской культуры. СПб.: Изд-во им. Н.И. Новикова, 20II. 536 с. Жуков В.Н. Третий Завет Дмитрия Мережковского // Мережковский Д.С. Иисус Неизвестный. М.: Республика, І996. С. 682-683. Ким М. Брак и семья у В. Розанова и Д. Мережковского: (две интерпретации «Крейцеровой сонаты» и «Анны Карениной» Л. Толстого) // Вестник РГГУ. Филологические науки. Литературоведение. Фольклористика. 2012. № I8. C. $124-\mathrm{I} 34$. Коростелев О.А. Главная трилогия Д.С. Мережковского // Мережковский Д.С. Собр. соч.: в 20 т. М.: Дмитрий Сечин, 20I7. Т. І4: Тайна Трех: Египет и Вавилон; Тайна Запада: Атлантида-Европа / сост., подгот. текста, послесл., коммент. О.А. Коростелева и Е.А. Андрущенко, при участии А.В. Журбиной. С. 768-775. Матич О. Эротическая утопия: новое религиозное сознание и fin de siècle в России. М.: НЛО, 2008. 400 с. Николюкин А.Н. Феномен Мережковского // Мережковский: pro et contra. Личность и творчество Дмитрия Мережковского в оценке современников: антология. СПб.: РХГА, 200I. С. 7-28. Полонский В.В. Хилиастическая трансформация новозаветной образности в поздней историософии Д.С. Мережковского // Новозаветные образы и сюжеты в культуре русского модернизма / [сост. и отв. ред.: О.А. Богданова, А.Г. Гачева]. М.: Индрик, 2018. С. 400-42I. Сурова А.Б. Религиозная апологетика пола в творчестве В.В. Розанова // Электронное научное издание Альманах Пространство и Время. 2оІ4. Т. 7. Вып. І. URL: http://j-spacetime.com/actual\%2ocontent/t7vi/index.php (дата обращения: IO.04.2020).

I4 Холиков А.А. Пол как «семантическое поле» во втором прижизненном полном собрании сочинений Д.С. Мережковского // Вестник МГОУ. 2013. № 3 . URL: https://evestnik-mgou.ru/ru/Issues/View/ı3 (дата обращения: Іо.04.2020). Эконен К. Творец, субъект, женщина. Стратегии женского письма в русском символизме. М.: НЛО, 20II. 400 с. Bedford C.H. The Seeker: D.S. Merezhkovsky. Lawrence/Manhattan/Wichita: University Press of Kansas, I975. 222 p.

Engelstein L. The Keys to Happiness: Sex and the Search for Modernity in Fin-de-Siècle Russia. Ithaca; London, I992. 480 р. [Рус. перевод: Энгельштейн Л. Ключи счастья. 
Секс и поиски путей обновления России на рубеже XIX-XX веков. M.: Терра, I996. 572 c.]

I8 Naiman E. Sex in Public: The Incarnation of Early Soviet Ideology. Princeton, I997. $307 \mathrm{p}$.

\section{Источники}

I9 Адамович Г. Мережковский // Мережковский: pro et contra. Личность и творчество Дмитрия Мережковского в оценке современников: антология. СПб.: РХГА, 200I. С. 389-40I.

20 Бердяев Н.А. По поводу одной замечательной книги (О. Вейнингер. «Пол и характер») // Вопросы философии и психологии. г909. № 98. С. 494-50о.

2 Б Бердяев Н. Новое христианство (Д.С. Мережковский) // Мережковский: pro et contra. Личность и творчество Дмитрия Мережковского в оценке современников: антология. СПб.: РХГА, 200I. С. 33I-353.

22 Блок А. Мережковский // Мережковский: pro et contra. Личность и творчество Дмитрия Мережковского в оценке современников: антология. СПб.: РХГА, $200 \mathrm{I}$. С. 242-247.

23 Бугаев Б. Вейнингер о поле и характере // Весы. г909. № 2. С. 77-8I.

24 Вейнингер О. Пол и характер. Теоретическое исследование / пер. с нем. В. Лихтенштадта; под ред. и с предисл. А.Л. Волынского. СПб.: Посев, г9о8. 428 с.

25 Гиппис 3. Влюбленность. О любви. Арифметика любви. О женах // Русский эрос или Философия любви в России / сост. В.П. Шестаков. М.: Прогресс, І99I. С. 174-220.

26 Гиппиус З. Зверебог // Образование. г908. № 8. С. І8-27.

27 Иванов Вяч. О достоинстве женщины // Иванов Вяч. Собр. соч.: [в 4 т.]. Брюссель: [Foyer Oriental Chretien], I979. Т. 3 / под ред. Д.В. Иванова и О. Дешарт. C. I38-I40.

28 Климент Александрийский. Строматы. СПб.: Изд-во Олега Абышко, 2003. Т. г. $544 \mathrm{c}$.

29 Мережковский Д.С. Иисус Неизвестный. М.: Республика, г996. 688 с.

30 Мережковский Д.С. Собр. соч.: в 20 т. М.: Дмитрий Сечин, 20I7. Т. І4: Тайна Трех: Египет и Вавилон; Тайна Запада: Атлантида-Европа / сост., подгот. текста, послесл., коммент. О.А. Коростелева и Е.А. Андрущенко, при участии А.В. Журбиной. 807 с.

3 I Платон. Собр. соч.: в 4 т. / [общ. ред. А.Ф. Лосева и др.; примеч. А.А. Тахо-Годи]. М.: Мысль, І990-І994. - Т. 2 (М., І993). Т. 3 (М., І994).

32 Соловьев В.С. Смысл любви. Киев: «Лыбидь - Аски», г99г. 63 с. 


\section{References}

I Andrushchenko, E.A. "Nesvoevremennaia kniga” ["Untimely Book”]. Merezhkovskii D.S. Sobranie sochinenii: $v 20$ t. [Collected Works: in 20 Vols.], vol. I4, ed. by O.A. Korostelev, and E.A. Andrushchenko with participation of A.V. Zhurbina. Moscow, Dmitry Sechin Publ., 20I7, pp. 776-788. (In Russ.)

2 Bazarov, V. "Khristiane Tret'ego Zaveta i stroiteli Bashni Vavilonskoi” [“Christians of the Third Testament and the Builders of the Babel Tower"]. Merezhkovskii: pro et contra. Lichnost' i tvorchestvo Dmitriia Merezhkovskogo v otsenke sovremennikov: antologiia [Merezhkovsky: Pro et Contra. Personality and Works of Dmitry Merezhkovsky as Seen by His Contemporaries: Anthology]. St. Petersburg, Russian Christian Academy for the Humanities Publ., 200I, pp. I97-24I. (In Russ.)

3 Bershtein, E. "Tragediia pola: dve zametki o russkom veiningerianstve” ["A Tragedy of Gender: Two Notes on Weininger in Russia”]. Novoe literaturnoe obozrenie, no. 65, 2004, pp. 208-228. Available at: https://magazines.gorky.media/nlo/2004/I/ tragediya-pola-dve-zametki-o-russkom-vejningerianstve.html (Accessed Io April 2020). (In Russ.)

4 Brylina, I.V. "Pol kak istok zhizni: V.V. Rozanov, L.N. Tolstoi, M.I. Tsvetaeva” ["Gender as the Source of Life: Vassily Rozanov, Leo Tolstoy, Marina Tsvetaeva”]. Izvestiia Tomskogo politekhnicheskogo universiteta, vol. 3II, no. 7: Philosophy, Sociology and Culturology, 2007, pp. 98-I03. (In Russ.)

5 Dering-Smirnova, R. "Pasternak i Veininger" ["Pasternak and Weininger"]. Novoe literaturnoe obozrenie, no. 37, 1999, pp. 63-69. (In Russ.)

6 Zherebin, A.I. Vertikal'naia liniia. Venskii modern v smyslovom prostranstve russkoi kul'tury [A Vertical Line. Vienna Modern in the Semantic Space of Russian Culture]. St. Petersburg, Izdatel'stvo im. N.I. Novikova Publ., 20II. 536 p. (In Russ.) Zhukov, V.N. “Tretii Zavet Dmitriia Merezhkovskogo” [“The Third Testament of Dmitry Merezhkovsky"]. Merezhkovskii, D.S. Iisus Neizvestnyi [Jesus Unknown]. Moscow, Respublika Publ., I996, pp. 682-683. (In Russ.)

8 Kim, M. “Brak i sem'ia u V. Rozanova i D. Merezhkovskogo (dve interpretatsii 'Kreitserovoi sonaty’ i ‘Anny Kareninoi’ L. Tolstogo)” [“Marriage and Family by Vassily Rozanov and Dmitry Merezhkovsky (Two Interpretations of the Kreutzer Sonata and Anna Karenina by Leo Tolstoy)”]. Vestnik RGGU. Filologicheskie nauki. Literaturovedenie. Fol'kloristika, no. I8, 20I2, pp. I24-I34. (In Russ.)

9 Korostelev, O.A. “Glavnaia trilogiia D.S. Merezhkovskogo” ["Main Trilogy of Dmitry Merezhkovsky”]. Merezhkovsky, D.S. Sobranie sochinenii: v 20 t. [Collected Works in 20 Vols.], vol. I4, ed. by O.A. Korostelev, and E.A. Andrushchenko with participation of A.V. Zhurbina. Moscow, Dmitry Sechin Publ., 20I7, pp. 768-775. (In Russ.)

Io Matich, O. Eroticheskaia utopiia: novoe religioznoe soznanie ifin de siècle $v$ Rossii [Erotic Utopia: New Religious Consciousness and Fin-de-Siècle in Russia]. Moscow, NLO Publ., 2008. 400 p. (In Russ.) 
Nikoliukin, A. "Fenomen Merezhkovskogo" ["Merezhkovsky Phenomenon”]. Merezhkovskii: pro et contra. Lichnost' i tvorchestvo Dmitriia Merezhkovskogo v otsenke sovremennikov: antologiia [Merezhkovsky: Pro et Contra. Personality and Works of Dmitry Merezhkovsky as Seen by his Contemporaries: Anthology]. St. Petersburg, Russian Christian Academy for the Humanities Publ., 200I, pp. 7-28. (In Russ.)

I2 Polonskii, V.V. "Khiliasticheskaia transformatsiia novozavetnoi obraznosti v pozdnei istoriosofii D.S. Merezhkovskogo" ["Chiliastic Transformation of the New Testament Imagery in the Late Historiosophy of Dmitry Merezhkovsky"]. Bogdanova, O.A., and A.G. Gacheva, editors. Novozavetnye obrazy i siuzhety $v$ kul'ture russkogo modernizma [New Testament Images and Plots in the Culture of Russian Modernism]. Moscow, Indrik Publ., 20I8, pp. 400-42I. (In Russ.)

I3 Surova, A.B. "Religioznaia apologetika pola v tvorchestve V.V. Rozanova" ["Religious Apology of Gender in the Works of Vassily Rozanov"]. Elektronnoe nauchnoe izdanie Al'manakh Prostranstvo i Vremia [Electronic Academic Edition Space and Time. An Almanach], vol. 7, issue I, 20I4. Available at: http://j-spacetime.com/actual\%2O content/t7vi/index.php (Accessed Io April 2020). (In Russ.)

I4 Kholikov, A.A. "Pol kak 'semanticheskoe pole' vo vtorom prizhiznennom polnom sobranii sochinenii D.S. Merezhkovskogo” ["Gender as 'Semantic Field' in the Second Lifetime Complete Works of Dmitry Merezhkovsky"]. Elektronnyi zhurnal "Vestnik $M G O U ”$, no. 3, 20I3. Available at: www.evestnik-mgou.ru. (Accessed io April 2020). (In Russ.)

I5 Ekonen, K. Tvorets, sub"ekt, zhenshchina. Strategii zhenskogo pis'ma v russkom simvolizme [Creator, Subject, Woman. Strategies of Female Writing in Russian Symbolism]. Moscow, NLO Publ., 20II. 400 p. (In Russ.)

I6 Bedford, C. Harold. The Seeker: D.S. Merezhkovsky. Lawrence/Manhattan/Wichita, University Press of Kansas, I975. 222 p. (In English)

I7 Engelstein, Laura. The Keys to Happiness: Sex and the Search for Modernity in Fin-deSiècle Russia. Ithaca; London, I992. 480 p. (In English)

I8 Naiman, Eric. Sex in Public: The Incarnation of Early Soviet Ideology. Princeton, I997. 307 p. (In English) 